\title{
Lignin in Paper Mill Sludge is degraded by White-Rot Fungi in Submerged Fermentation
}

\author{
Yuanyuan Hong ${ }^{1,2}$, Mehdi Dashtban ${ }^{1,4}$, Sanfeng Chen ${ }^{2}$, Ruiqing Song ${ }^{3}$ and Wensheng Qin ${ }^{1 *}$ \\ ${ }^{1}$ Department of Biology, Lakehead University, Thunder Bay, ON, P7B 5E1, Canada \\ ${ }^{2}$ State Key Laboratory for Agrobiotechnology and College of Biological Sciences, China Agricultural University, Beijing 100193, China \\ ${ }^{3}$ Northeast Forestry University, 26 Hexing Road, Harbin 150040, China \\ ${ }^{4}$ School of Environmental Sciences, University of Guelph, Guelph, Ontario, N1G 2W1, Canada
}

\begin{abstract}
This study investigated biological treatment of paper mill sludge and lignin degradation by fungi. Four different Basidiomycetes white-rot fungi (WRF) were used: Coriolus versicolor, Tyromyces albidus, Trametes gallica and Pleurotus ostreatus. The fungi were cultured in submerged fermentation cultures with paper mill sludge. The $\mathrm{pH}$ values of the cultures and ligninolytic enzymes production profiles of the four fungi were monitored and reported here. The highest laccase activity of $202 \mathrm{U} / \mathrm{L}$ was obtained in T. albidus at day 25 while the maximum manganese-dependent peroxidase $(\mathrm{MnP})$ activity of $50 \mathrm{U} / \mathrm{L}$ was obtained in $C$. versicolor from day 15 to 25 . The $P$. ostreatus showed highest total cellulase activity with the peak of $0.26 \mu \mathrm{mol}$ at day 15 while the other three WRF showed negligible total cellulase activity. The lignin contents were significantly decreased in the four WRF-treated sludge samples and were confirmed by acetyl bromide and FTIR analyses. The results suggested that lignin was preferentially used and significantly degraded or converted in all the four WRF-treated sludge samples.
\end{abstract}

Keywords: Lignin; Biological treatments; Microbial processes; Lignocellulosic biomass; White-rot fungi (Wrf)

\section{Introduction}

The effluents from the pulp and paper industry cause considerable damage to the receiving waters if discharged untreated. They have high biochemical oxygen demand (BOD), chemical oxygen demand (COD) and contain chlorinated compounds, suspended solids (mainly fibers), fatty acids, lignin and sulphur compounds. Most of the solids are removed after the mechanical treatment resulting in a sludge that contains large quantities of fibers [1]. Because of more and more stringent environmental requirements, landfills are reaching full capacity and the development of alternative solutions or methods for treating paper mill sludge (PMS) are under pressure.

Paper mill sludge is a solid waste material composed of pulp residues and ash generated from the pulping and paper-making process [2]. It is a solid residue recovered from the wastewater. Paper mill sludges are distinctly different in composition, even between mills using the same pulp and paper manufacturing process. PMS consists primarily of polysaccharide material-cellulose, lignin and hemicelluloses [3]. The majority of the created sludge wastes (69\%) are disposed in landfill while $21 \%$ are incinerated. Currently, most sludge produced by pulp and paper mills is dewatered and landfilled. It is both economically and environmentally beneficial to find treatment methods that cut down on landfill deposits.

Lignin is an amorphous highly-branched polymer present in vascular plants and accounts for up to $30 \%$ of the dry weight of the plant and biomass [4]. Lignin generally contains three precursor aromatic alcohols including coniferyl alcohol, sinapyl and $p$-coumaryl [5]. These precursors form the guaiacyl- (G), syringyl- (S) and p-hydroxyphenyl $(\mathrm{H})$ subunits in the lignin molecule, respectively [6]. The subunits ratio, and consequently, the lignin composition, varies between different plant groups [7]. Lignin acts as a barrier to any solutions or enzymes by linking to both hemicellulose and cellulose. This prevents penetration of lignocellulolytic enzymes to the interior lignocellulosic structure [8]. The complex linking of lignin to cellulose and hemicellulose makes physical and chemical removal of lignin in biomass inefficient and energy intensive. Thermal, mechanical and chemical conversions are extensively reviewed by Bridgwater, Sun and Cheng and Hendriks and Zeeman [9]. Recently, biological methods for lignin removal or modification have received more and more attention by many research groups.

Biological treatments use microorganisms for the degradation and conversion of organic materials [9]. Dionisi et al. [10] reviewed the literature on three microbial processes and compared the rates of microbial processes with those of the alternative physio-chemical pretreatment processes. The best pretreatment method depends on many factors such as type of lignocellulosic biomass, process parameters, environmental impact, economical feasibility, etc [11].

White-rot fungi (WRF) are known as efficient lignin degrading microorganisms. Du studied the lignin degradation using wheat straw as a substrate by nine different basidiomycetous fungi [12]. Among the studied WRF, four of them including P. ostreatus sensu Cooke, C. versicolor (L.) Quel., T. albidus (Schaeff.) Donk, and T. gallica Fr. were reported to be more efficient in lignin degradation. The four aforementioned WRF preferentially work on lignin in a selective manner. Hong et al. examined four fungi including Coriolus versicolor, Tyromyces albidus, Trametes gallica and Pleurotus ostreatus in submerged media containing peat [8]. The enzymatic profiles of the fungi were assessed. They found the predominant ligninolytic enzyme during the fermentation process using a peat substrate was laccase. T. gallica was the most active one of the four. The production of total

*Corresponding author: Wensheng Qin, Department of Biology, Lakehead University, Thunder Bay, ON, P7B 5E1, Canada, Tel: 807-343 8467; Fax: 8073467796; E-mail: wqin@lakeheadu.ca

Received March 25, 2015; Accepted May 28, 2015; Published June 04, 2015

Citation: Hong Y, Dashtban M, Chen S, Song R, Qin W (2015) Lignin in Paper Mill Sludge is degraded by White-Rot Fungi in Submerged Fermentation. J Microb Biochem Technol 7: 177-181. doi:10.4172/1948-5948.1000201

Copyright: (c) 2015 Hong Y, et al. This is an open-access article distributed under the terms of the Creative Commons Attribution License, which permits unrestricted use, distribution, and reproduction in any medium, provided the original author and source are credited. 
cellulase was for all four WRF [8]. These fungi produce ligninolytic enzymes such as lignin peroxidase (LiP), manganese dependent peroxidase $(\mathrm{MnP})$ and laccase. They also secrete other accessory and lignin-modifying enzymes.

The aim of this research was to (i) study the production of lignindegrading enzyme complexes by the four WRF under different conditions in submerged fermentation using paper mill sludge as a substrate; (ii) to study the effect of these fungi in lignin modification and degradation.

\section{Materials and Methods}

\section{Chemicals}

The chemicals and reagents used in this research were analytical grade. Paper mill sludge (obtained from a paper mill in Canada) was dried at $37^{\circ} \mathrm{C}$ then ground in a coffee grinder. The powders were filtered through a mesh screen, and then were used for making the media to be used in the submerged fermentation process.

\section{Fungal strains and culture conditions}

Four WRF strains P. ostreatus sensu Cooke, C. versicolor (L.) Quel., T. albidus (Schaeff.) Donk, and T. gallica Fr. were used in the current study. They were isolated in the laboratory of Dr. Ruiqing Song at Northeast Forestry University, China. The fungi were grown and maintained on potato dextrose agar (PDA) supplemented with 20.0 $\mathrm{g} / \mathrm{L}$ sucrose, $3.0 \mathrm{~g} / \mathrm{L} \mathrm{KH}_{2} \mathrm{PO}_{4}$, and $2.0 \mathrm{~g} / \mathrm{L} \mathrm{MgSO}_{4}$. Strains were grown in $250-\mathrm{mL}$ flasks containing $50 \mathrm{~mL}$ liquid sludge medium modified from $\mathrm{Du}$ et al. [12]: $15.0 \mathrm{~g} / \mathrm{L}$ potato dextrose, $3.0 \mathrm{~g} / \mathrm{L} \mathrm{KH}_{2} \mathrm{PO}_{4}, 3.1 \mathrm{~g} / \mathrm{L}$ $\mathrm{MgSO}_{4} \cdot 7 \mathrm{H}_{2} \mathrm{O}, 5.0 \mathrm{~g} / \mathrm{L}$ ammonium tartrate, $20 \mathrm{~g} / \mathrm{L}$ sludge and $50 \mathrm{ml} / \mathrm{L}$ trace element solution. The trace element solution contained $3.0 \mathrm{~g} / \mathrm{L}$ $\mathrm{MgSO}_{4} \cdot 7 \mathrm{H}_{2} \mathrm{O}, 0.5 \mathrm{~g} / \mathrm{L} \mathrm{MnSO}_{4}, 1.0 \mathrm{~g} / \mathrm{L} \mathrm{NaCl}, 0.1 \mathrm{~g} / \mathrm{L} \mathrm{FeSO}_{4} \cdot 7 \mathrm{H}_{2} \mathrm{O}, 0.1 \mathrm{~g} / \mathrm{L}$ $\mathrm{CoCl}_{2}, 0.1 \mathrm{~g} / \mathrm{L} \mathrm{ZnSO}_{4} \cdot 7 \mathrm{H}_{2} \mathrm{O}, 0.1 \mathrm{~g} / \mathrm{L} \mathrm{CuSO}_{4}, 10 \mathrm{mg} / \mathrm{L} \mathrm{AlK}\left(\mathrm{SO}_{4}\right)_{2} \cdot 12 \mathrm{H}_{2} \mathrm{O}$, $10 \mathrm{mg} / \mathrm{L} \mathrm{H}_{3} \mathrm{BO}_{3}, 10 \mathrm{mg} / \mathrm{L} \mathrm{Na}_{2} \mathrm{MoO}_{4} \cdot 2 \mathrm{H}_{2} \mathrm{O}$ and $1.5 \mathrm{~g} / \mathrm{L}$ nitrilotriacetic acid (NTA). The $\mathrm{pH}$ of the medium was adjusted to $\mathrm{pH} 5.0$ by adding $\mathrm{H}_{2} \mathrm{SO}_{4}$.

\section{Inoculum preparation}

Fungi were pre-grown in potato dextrose agar (PDA) broth medium for several days. The mycelia were then cut to small pieces (shorter than $1 \mathrm{~mm}$ ) and grown in a new PDA liquid medium until pellets were formed. These pellets were used as inocula for the liquid sludge medium. The fungi were grown in $250 \mathrm{~mL}$ flasks containing 50 $\mathrm{mL}$ liquid sludge medium and maintained at room temperature for 25 days statically. Each fungus was grown in 15 flasks. Three flasks of each fungus were used for collecting samples every 5 days to complete enzyme activity measurements. The broth cultures of fungi were first filtered and the filtrates were collected by centrifugation at $12,000 \mathrm{~g}$ for 2 minutes [8].The supernatant was used as the source of enzyme for all of the enzymatic assays.

\section{Enzyme activities}

One unit of enzyme activity was defined as the amount of enzyme that transformed $1 \mu \mathrm{mol}$ of substrate per min. The activities of laccase, $\mathrm{MnP}$, and Lip were measured by using a previously described method [8]. Laccase activity was determined by monitoring the oxidation of 2 , 2'-Azinobis (3-ethylbenzothiazoline-6-sulfonic Acid Ammonium Salt) (ABTS) at $436 \mathrm{~nm}$. The reaction mixture contained $1 \mathrm{mM}$ ABTS and $100 \mathrm{mM}$ sodium acetate buffer $(\mathrm{pH} 4.5)$. The extinction co-efficient $(\varepsilon)$ of ABTS at $436 \mathrm{~nm}$ is $29300 \mathrm{M}^{-1} \mathrm{~cm}^{-1}[13]$.

$\mathrm{MnP}$ activity was determined by monitoring the oxidation of 2,6-dimethoxyphenol (DMP) at $469 \mathrm{~nm}$. The reaction mixture contained $1 \mathrm{mM}$ DMP, $1 \mathrm{mM} \mathrm{MnSO}, 100 \mathrm{mM}$ sodium tartrate $(\mathrm{pH}$ 4.5 ) and $0.1 \mathrm{mM} \mathrm{H}_{2} \mathrm{O}_{2}$. The MnP activity was corrected for MIP activity by subtracting the activity obtained at $\mathrm{pH} 4.5$ in the absence of $\mathrm{MnSO}_{4}$. The extinction co-efficient $(\varepsilon)$ of DMP at $469 \mathrm{~nm}$ is $27500 \mathrm{M}^{-1} \mathrm{~cm}^{-1}[14]$.

LiP activity was determined by monitoring the oxidation of azure $\mathrm{B}$ at $651 \mathrm{~nm}$. The reaction mixture contained $0.032 \mathrm{mM}$ azure $\mathrm{B}, 50 \mathrm{mM}$ sodium tartrate ( $\mathrm{pH} 3.0$ ) and $0.4 \mathrm{mM} \mathrm{H}_{2} \mathrm{O}_{2}$. The extinction co-efficient (ع) of azure $B$ at $651 \mathrm{~nm}$ is $48800 \mathrm{M}^{-1} \mathrm{~cm}^{-1}$ [15].

\section{Filter Paper Assay (FPA) and determination of reducing sugar content}

A microplate based filter paper assay, described by Sun et al. was carried out to measure the total cellulase activity as described by Hong et al. $[8,16]$. In brief, the cell free culture supernatant was diluted 50 times with $50 \mathrm{mM} \mathrm{NaAc}(\mathrm{pH} 4.8)$. Sixty (60) $\mu \mathrm{L}$ of each sample was placed in a well containing a $6 \mathrm{~mm}$ diameter filter paper disk (Whatman No. 1, with average weight of $3.0 \mathrm{mg}$ each, Thermo Fisher Scientific, Canada). Disks were made using a standard office hole punch. Reagent blank controls containing only $60 \mu \mathrm{L}$ of $50 \mathrm{mM} \mathrm{NaAc}$ buffer and substrate control containing the filter paper and $60 \mu \mathrm{L}$ of 50 $\mathrm{mM} \mathrm{NaAc}$ buffer were also run. A negative control with no filter paper was run to exclude the background of reducing sugars found in the enzyme supernatant from the results. A glucose standard curve with a range of 0 to $1.0 \mathrm{mg} / \mathrm{mL}$ was run. Triplicates of samples and standards were used.

Following the procedures adopted by Hong et al. the microplates were sealed with paraffin membrane, then covered in a Ziploc bag and incubated in a $50^{\circ} \mathrm{C}$ water bath for $60 \mathrm{~min}$ [8]. Then $120 \mu \mathrm{L}$ of 3,5-dinitrosalicylic acid (DNS reagent) was added to each well to measure the released reducing sugar, and the plate resealed with paraffin. The plate was placed in a boiling water bath for $5 \mathrm{~min}$ to develop the color. A $100 \mu \mathrm{L}$ aliquot was transferred to a new 96-well flat-bottom microplate, and the absorbance at $540 \mathrm{~nm}$ was measured using an xMark Microplate Spectrophotometer (Bio-Rad, Canada). Total reducing sugars generated during the assay was estimated as glucose equivalents. To calculate glucose equivalents, the absorbance of the sample was converted into a concentration using the standard curve.

\section{Analysis of lignin in paper mill sludge by acetyl bromide digestion}

Lignin contents of paper mill sludge were determined by acetyl bromide treatment (25\% in acetic acid) and then the absorbance was determined at $280 \mathrm{~nm}$ [17].

\section{FTIR analyses of untreated and treated paper mill sludge}

To investigate the modification of lignin functional groups of WRFtreated paper mill sludge, Fourier transform infrared spectroscopic (FTIR) spectra $\left(1,900\right.$ to $\left.700 \mathrm{~cm}^{-1}\right)$ were obtained and compared to untreated paper mill sludge (Lakehead University Instrumentation Lab, Thunder Bay, Canada). A Tensor 37 FTIR (Bruker Optics, Germany) with a resolution of $4 \mathrm{~cm}^{-1}$ and 32 scans per sample was used. The experiment was done using approximately $2 \mathrm{mg}$ of each sample and applying a MIRacle ATR accessory with high-pressure clamp (PIKE Technologies, Madison, WI, USA).

\section{Data processing and statistical analysis}

The average values of three independent experiments were used for 
experimental results. Using a Microsoft Excel spreadsheet the average and standard error of the mean were calculated. To test the statistical significance of differences between lignin content of paper mill sludge (PMS) before and after fungal treatment PRISM 5 software was used to complete a one-way analysis of variance (one-way ANOVA) at a confidence level of $95 \%(\alpha=0.05)$.

\section{Results and Discussion}

\section{The $\mathrm{pH}$ value change in submerged fermentation process}

The $\mathrm{pH}$ values of the four WRF cultured using a submerged fermentation process using paper mill sludge as the substrate was studied. They were monitored every 5 days over a 25 day period (Figure 1). The $\mathrm{pH}$ value of cultured C. versicolor and T. albidus decreased from 6.0 to around 4.0 over the first 10 days and T. gallica over 15 days, then continuously increased over the remaining days. The $\mathrm{pH}$ value of cultured $P$. ostreatus slowly changed over the 25 days experiment with only a slight decrease by the end of the 25 day experiment. Pellinen et al. suggested that the $\mathrm{pH}$ value of the unbuffered culture medium decreases during the incubation due to the releasing of acidic lignin degraded products [18]. The different $\mathrm{pH}$ trend in P. ostreatus could be due to its slow growth rate comparing to the other three fungi used in the study. This would suggest that the $\mathrm{pH}$ of the medium would increase if the experiment were extended (Figure 1).

\section{Lactase activities}

Laccase activities of $C$. versicolor and T. gallica gradually increased over the experiment starting at day 5 (Figure 2). P. ostreatus showed a peak of laccase activity with $67 \mathrm{U} / \mathrm{L}$ at the day 15 . The laccase activity of $T$. albidus has a peak $(107 \mathrm{U} / \mathrm{L})$ at $15^{\text {th }}$ day, but decreased again for the $20^{\text {th }}$. The laccase activity gradually increased from that point onwards. Among the four fungi studied here, T. albidus was the most active laccase producer with about $202 \mathrm{U} / \mathrm{L}$ laccase activity at the last time point (day 25) (Figure 2). So it is critical to determine a right time point for maximum laccase production in industry. The trend of laccase activities of $P$. ostreatus is different with the other three strains. We assume this is because its production of laccase is more sensitive to medium acidification than the other three WRF. Except for $P$. ostreatus, laccase activities of the WRF were continuously increased. The trend of laccase activity is highly variable. Dinis et al. [19] found

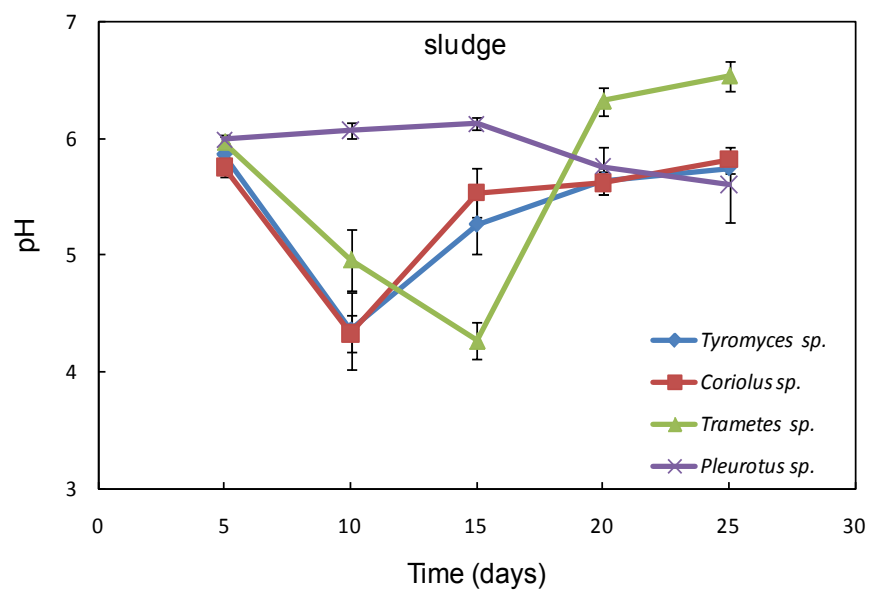

Figure 1: The $\mathrm{pH}$ value of the four white rot fungi in submerged fermentation process by using sludge as substrates. The $\mathrm{pH}$ of the medium was adjusted to $\mathrm{pH} 5.0$ at the beginning.

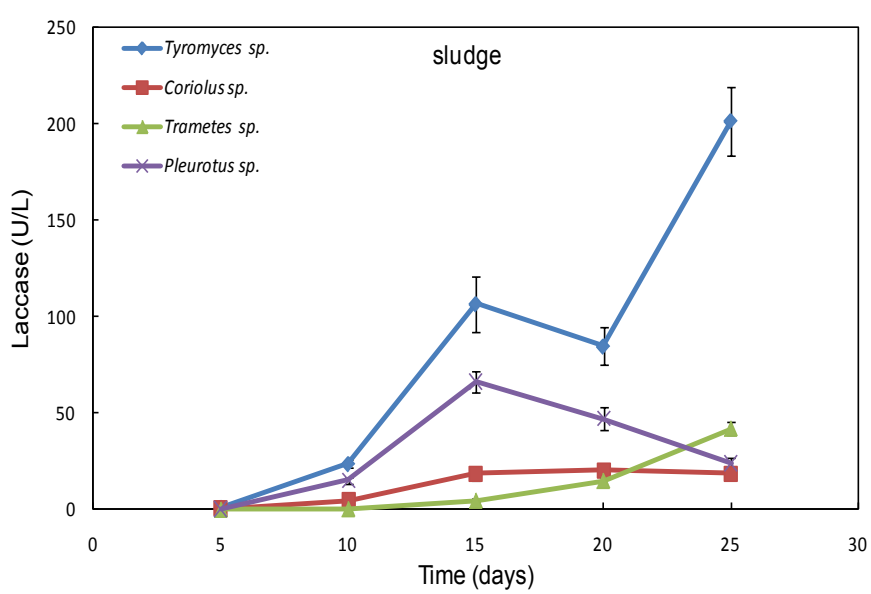

Figure 2: Laccase activities of the four white rot fungi in submerged fermentation using sludge containing media.

that maximum laccase activities were detected during the first 10 days of wheat straw incubation by $T$. versicolor $(C$. versicolor). This is because lignin enzyme production by WRF is highly dependent on species, strains, lignocellulosic substrates, medium and fermentation method [20] (Figure 2).

\section{MnP activities}

All four WRF secreted a notable quantity of manganese peroxidase (MP) (data not shown). However, they produced little manganesedependent peroxidase except for $C$. versicolor. After the 25 days submerged fermentation, $C$. versicolor produced relatively high yields of $\mathrm{MnP}$. In Winquist's study, C. versicolor also produced relatively higher levels of $\mathrm{MnP}$, compared with the other fungi including Pleurotus ostreatus DSM 11191, T. hirsuta K 21a and Cerrena unicolor $\mathrm{T} 71$ [21]. The other three WRF studied here, produced MnP activities less than $2 \mathrm{U} / \mathrm{L}$ (Figure 3). Lower MnP activity in T. albidus, T. gallica and $P$. ostreatus could be due to the growth conditions such as medium composition. As in the study of Sun et al., HcLn (high amounts of carbon source and low amounts of nitrogen source) and LcHn (low amounts of carbon source and high amounts of nitrogen source) media were used to investigate the production of T. gallica ligninases under both agitated and stationary incubations [16]. Laccase activities were found in the four cultivations. No LiP activities were detected in any of the four cultivations, consistent with Sun et al. [16]. MnP activity was detected only under HcLn. Similar results with low MnP activity were reported using other WRF. In these cases, WRF secreted high laccase activity but no $\mathrm{MnP}$ or trace amounts of $\mathrm{MnP}$ activities were detected by the majority of the fungi tested [22-24] (Figure 3).

\section{LiP activities}

No significant LiP activity was detected in any of the four WRF in submerged fermentation using paper mill sludge as the substrate. Studies have been shown that many WRF including Pleurotus species have been recognized to produce no typical LiP [25]. Additionally, LiP activity was not detected at all in medium cultured with C. versicolor using Olive mill wastewater as the substrate [26]. It has been suggested that $\mathrm{LiP}$ production is influenced by the $\mathrm{C} / \mathrm{N}$ ratio [27]. It has been shown that some WRF are able to produce all different type of ligninase enzymes while other WRF only produces one or two types. Our results demonstrated that none of our four WRF secretes detectable LiP under the used experimental conditions. 


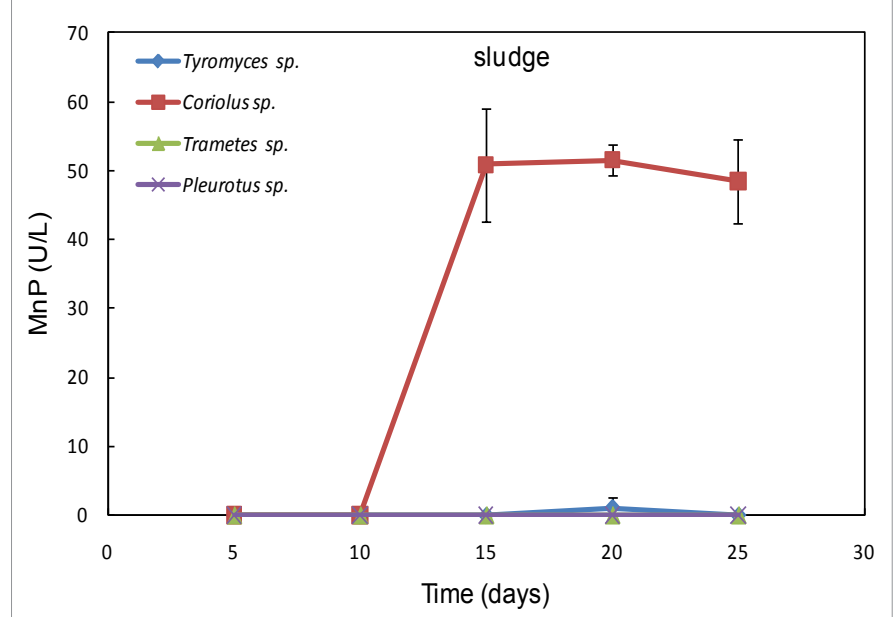

Figure 3: MnP activities of the four white rot fungi in submerged fermentation using paper mill sludge containing media.

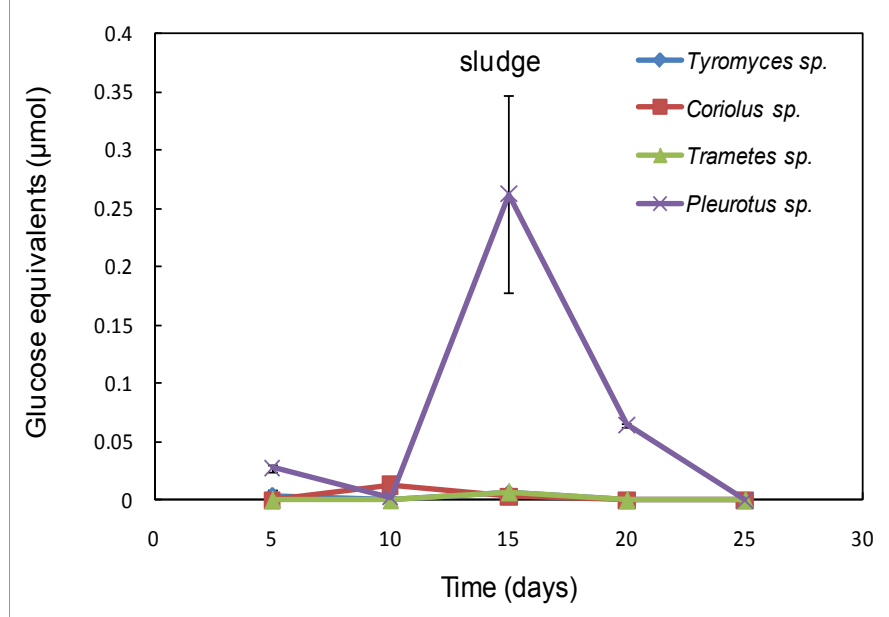

Figure 4: Total cellulase activities of the four white rot fungi in submerged fermentation using sludge containing media.

\section{Total cellulase activities}

Significant total cellulase activity was only detected in P. ostreatus (Figure 4). For the P. ostreatus the lowest values were observed in the first 10 days of incubation. $P$. ostreatus showed a maximum total cellulase activity of $0.26 \mu \mathrm{mol}$ at 15 days of incubation. These relatively low values of cellulolytic activity were mainly due to the selectively use of lignin as the substrate by fungi. This is important, especially for the maximum lignin breakdown during pre-treatment using fungi (Figure $4)$.

\section{Lignin content measurement}

The acetyl bromide procedure for spectrophotometrically determining lignin in wood and wood pulp samples was used to measure the lignin content of paper mill sludge [17]. The lignin of woods and papermaking pulps contains the acid-insoluble (Klason) and acidsoluble lignin, the conventional method for lignin measurement uses sulphuric acid. This procedure requires large samples and complex steps. The acetyl bromide procedure only needs small samples and is very convenient. The lignin content can be dissolved in $25 \%$ acetyl bromide in acetic acid and then measured by absorbance at $280 \mathrm{~nm}$. Our results showed that the lignin content of sludge samples treated by all the four WRF decreased after one month incubation (Figure 5).

\section{FTIR analyses of untreated and pretreated paper mill sludge}

The FTIR was used to qualitatively determine the chemical changes in sludge with or without WRF treatment. The FTIR spectra for WRF-treated sludge samples were compared to untreated sludge and shown in Figure 6, while the main assignments of functional groups in FTIR bands are listed in Table 1. All of the four WRF-treated sludge samples showed decreased adsorption in bands at $1,373 \mathrm{~cm}^{-1}-1,529$ $\mathrm{cm}^{-1}$ compared to the untreated sample. The band at $1,512 \mathrm{~cm}^{-1}$ are attributed to aromatic skeletal stretching in lignin, and the bands at $1,424 \mathrm{~cm}^{-1}$ and $1,462 \mathrm{~cm}^{-1}$ are attributed to $\mathrm{C}-\mathrm{H}$ deformation within the methyl groups of lignin. Our results suggested that lignin was removed in all four of the WRF-treated sludge samples.

This is a prescreening test about the waste degradation abilities of the four white rot fungi. The four white rot fungi are good lignin degraders, for future development of fungal bioreactor, more studies about the fermentation parameters, include incubation temperature, media, $\mathrm{pH}$ and so on are needed (Figure 6) (Table 1).

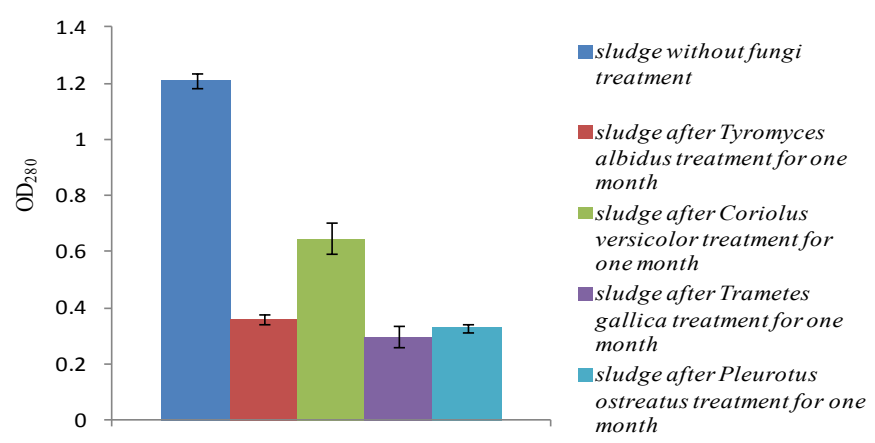

Figure 5: Lignin of paper mill sludge was degraded by white rot fungi (by acetyl bromide method).

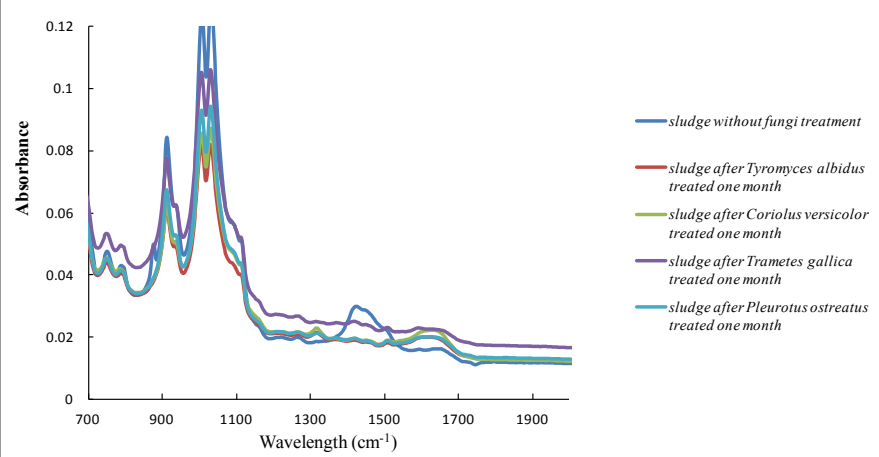

Figure 6: $1373-1529 \mathrm{~cm}-1$ regions were all decreased after fungal treatment.

\begin{tabular}{|c|c|}
\hline Band assignment & Wavenumbers $\left(\mathrm{cm}^{-1}\right)$ \\
\hline $\mathrm{C}=\mathrm{C}$ of aromatic skeletal (lignin) & 1512 \\
\hline $\mathrm{C}-\mathrm{H}$ deformation in lignin and carbohydrate & 1462 \\
\hline $\mathrm{C}-\mathrm{H}$ deformation in lignin and carbohydrate & 1424 \\
\hline
\end{tabular}

Table 1: Main assignments of lignin FTIR bands of lime wood (Carmen et al, 2010). 
Citation: Hong Y, Dashtban M, Chen S, Song R, Qin W (2015) Lignin in Paper Mill Sludge is degraded by White-Rot Fungi in Submerged Fermentation. J Microb Biochem Technol 7: 177-181. doi:10.4172/1948-5948.1000201

\section{Conclusions}

The interest in utilizing ligninolytic enzyme producing fungi such as WRF for biological pretreatment of lignocellulosic residues has increased rapidly. In this study, PMS was used as the substrate for submerged fermentation cultures of four different WRF. All four WRF showed relatively high laccase activity whereas MnP activity was only remarkably produced by $C$. versicolor. Laccases are widely distributed in different WRF with high potential industrial applications. The cellulase production of the WRF was very low with the exception of $P$. ostreatus. The lignin contents of PMS-treated samples were significantly decreased after the treatment. This suggests the studied WRF are able to selectively degrade lignin.

\section{Acknowledgment}

Y. H. was supported by China Scholarship Council (CSC) Graduate Scholarship Program, M. D. was supported by Ontario Graduate Scholarship (OGS). This work was supported by Ontario Research Chair Funding to W. Q.

\section{References}

1. Ochoa de Alda, J.A.G. (2008) Feasibility of recycling pulp and paper mill sludge in the paper and board industries. Resources, Conservation and Recycling 52: 965-972.

2. Shi,A, Kang L, Lee YY (2014) Production of Lactic Acid from the Mixture of Softwood Pre-hydrolysate and Paper Mill Sludge by Simultaneous Saccharification and Fermentation. Appl Biochem Biotechnol 175: 2741-2754.

3. Jackson MJ, Line MA (2009) Organic Composition of a Pulp and Paper Mill Sludge Determined by FTIR, 13C CP MAS NMR, and Chemical Extraction Techniques. J Agric Food Chem 45: 2354-2358.

4. Bugg TDH, Ahmad M, Hardiman EM, Singh R (2011) Pathways for degradation of lignin in bacteria and fungi. Nat Prod Rep 28: 1883-1896.

5. Wei H, Xu Q, Taylor LE 2nd, Baker JO, Tucker MP, Ding SY (2009) Natural paradigms of plant cell wall degradation. Curr Opin Biotechnol 20: 330-338.

6. Martinez AT, Speranza M, Ruiz-Duenas FJ, Ferreira P, Camarero S, et al (2005) Biodegradation of lignocellulosics: microbial, chemical, and enzymatic aspects of the fungal attack of lignin. Int Microbiol 8: 195-204.

7. Dashtban M, Schraft H, Syed TA, Qin WS (2010) Fungal biodegradation and enzymatic modification of lignin. Int J Biochem Mol Biol 1: 36-50.

8. Hong Y, Dashtban M, Chen S, Song R, Qin W (2012) Enzyme Production and Lignin Degradation by Four Basidiomycetous Fungi in Submerged Fermentation of Peat Containing Medium. Int J of Bio 14:1: 172-180.

9. Mathews SK, Pawluk J, Grundes AM (2015) Bacterial biodegradation and bioconversaion of industrial lignocellulosic streams. Appl Microbiol Biotechnol 99: 2939-2954.

10. Dionisi D, Anderson JA, Aulenta F, McCue A, Paton G (2014) The potential of microbial processes for lignocellulosic biomass conversion to ethanol: a review. J Chem Technol Biotechnol 90: 366-383.

11. Behera S, Arora R, Nandhagopal N, Kumar S (2014) Importance of chemical pretreatment for bioconversion of lignocellulosic biomass. Renewable and Sustainable Energy Reviews 36: 91-106.

12. Du HP, Song RQ, Wang YQ (2006) Comparative Study on the Lignocellulolytic Enzymes Produced by Fungi. Forestry Science \& Technology 31: 20-24.

13. Jauregui J, Valderrama B, Albores A, Vazquez-Duhalt R (2003) Microsomal transformation of organophosphorus pesticides by white rot fungi. Biodegradation 14: 397-406.
14. Heinfling A, Martínez MJ, Martínez AT, Bergbauer M, Szewzyk U (1998) Transformation of Industrial Dyes by Manganese Peroxidases from Bjerkandera adusta and Pleurotus eryngii in a Manganese-Independent Reaction. Appl Environ Microbiol 64: 2788-2793.

15. Park C, Lee M, Lee B, Kim SW, Chase HA, et al. (2007) Biodegradation and biosorption for decolorization of synthetic dyes by Funalia trogii. Biochem Eng J 36: 59-65.

16. Sun X, Zhang RH, Zhang YZ (2004) Production of lignocellulolytic enzymes by Trametes gallica and detection of polysaccharide hydrolase and laccase activities in polyacrylamide gels. J Basic Microbiol 44: 220-231.

17. Liyama K, Wallis AFA (1988) An improved acetyl bromide procedure fo determining lignin in woods and wood pulps. Wood Sci Technol 22: 271-280.

18. Pellinen J, Abuhasan J, Joyce TW, Chang HM (1989) Biological delignification of pulp by Phanerochaete chrysosporium. J Biotechnol 10: 161-170.

19. Dinis MJ, Bezerra RM, Nunes F, Dias AA, Guedes CV, et al. (2009) Modification of wheat straw lignin by solid state fermentation with white-rot fungi. Bioresour Technol 100: 4829-4835

20. Elisashvili V, Kachlishvili E, Penninckx M (2008) Effect of growth substrate, method of fermentation, and nitrogen source on lignocellulose-degrading enzymes production by white-rot basidiomycetes. J Ind Microbiol Biotechno 35: 1531-1538.

21. Winquist E, Moilanen U, Mettala A, Leisola M, Hatakka A (2008) Production of lignin modifying enzymes on industrial waste material by solid-state cultivation of fungi. Biochem Eng J 42: 128-132.

22. Elisashvili V, Kachlishvili E (2009) Physiological regulation of laccase and manganese peroxidase production by white-rot Basidiomycetes. J Biotechnol 144: $37-42$.

23. Songulashvili G, Elisashvili V, Wasser SP, Nevo E, Hadar Y (2007) Basidiomycetes laccase and manganese peroxidase activity in submerged fermentation of food industry wastes. Enzyme Microb Technol 41: 57-61.

24. Elisashvili V, Kachlishvili E, Tsiklauri N, Metreveli E, Khardziani T, et al. (2009) Lignocellulose-degrading enzyme production by white-rot Basidiomycetes isolated from the forests of Georgia. World J Microbiol Biotechnol 25: 331-339.

25. Kamitsuji H, Y. Honda, Watanabe T, Kuwahara M (2004) Production and induction of manganese peroxidase isozymes in a white-rot fungus Pleurotus ostreatus. Appl Microbiol Biotechnol 65: 287-294.

26. Ergul FE, Sargın S, Ongen G, Sukan FV (2009) Dephenolisation of olive mil wastewater using adapted Trametes versicolor. Int Biodeterior Biodegradation 63: 1-6.

27. Tien M, Kirk TK (1988) Lignin peroxidase of Phanerochaete chrysosporium. Methods Enzymol 161: 238-249. 